The successor to the journal Music Review, Nineteenth-Century Music Review aims to locate music within the widest possible framework of intellectual activity pertaining to the long nineteenth century (c.1789-1914). It particularly welcomes interdisciplinary scholarship that explores music within the context of other artistic and scientific discourses. Articles with fine visual or iconographic content are encouraged, as are those rich in musically illustrative material. Articles accepted for publication will reflect a diversity of critical viewpoints.

\title{
Contents of Volume 2, Issue 2
}

Articles

\author{
Thérèse Radic \\ Janice B. Stockigt \\ Kerry Murphy \\ Jennifer Hill \\ Suzanne Cole
}

Jennifer Royle
Major Choral Organizations in Late Nineteenth-Century Melbourne

A Study of British Influence on Musical Taste and Programming: New Choral Works Introduced to Audiences by the Melbourne Philharmonic Society, 1876-1901

'Volk von Brüdern': The German-speaking Liedertafel in Melbourne

'A Source of Enjoyment': The Social Dimension of the Melbourne Liedertafels in the Late Nineteenth Century

'As Much by Force of Circumstances as by Ambition': The Programming Practices of the Melbourne Liedertafel Societies, 1880-1905

Musical (Ad)venturers: Colonial Composers and Composition in Melbourne, 1870-1901

Book Reviews

CD Review Article

Nigel Simeone

Debussy: Piano Works, Vols One-Four

CD Reviews

Score Reviews

Published in association with the Centre for Nineteenth-Century Music, Durham University, UK

Cover illustration: Metropolitan Liedertafel smoke-night concert, 1875: Julius Herz conducting. Engraving by Samuel

Calvert, Illustrated Australian News for Home Readers (3 Nov. 1875). Reproduced by kind permission of the Liedertafel Collection, Grainger Museum, University of Melbourne, Australia.

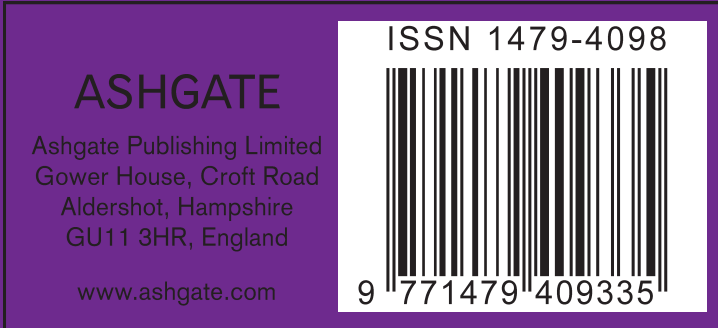

